\title{
Effect on performance audit implementation of good corporate governance in kab.Luwu (Case Study Inspectorate Kab.Luwu)
}

\author{
Rahmawati, A. \\ Hasanuddin University, Indonesia \\ rahmawati345@yahoo.co.id
}

\begin{abstract}
This paper describes how internal audit can support Good Corporate Governance in local government. How auditor capability and quantity can be accepted by 33 department of the local government Luwu. It also finds that Auditor capacity to do audit with independency, professionalisms and quality of auditor. This paper elaborates that the internal audit such as finance audit, compliance audit, and operational audit is required in local government to decrease fraud before the external audit find, and can be good for corporate governance. One of the things that can realize good corporate governance is seen from the performance of any organization of government activities, good performance in terms of achieving policy objectives, regulations and applicable law, the achievement of performance in an efficient, effective, and economical, as well as the compatibility between the performance achieved with established criteria. To assess the extent to which the achievement of local government performance in serving the interests of society, it is necessary to audit the performance. The purpose of this study was to determine the effect of Internal Audit on the implementation of good corporate governance in local government Luwu. The sample in this study was all local governments Internal Auditor in Luwu district Inspectorate office. The collection of information is done by compiling a list of questions that are appropriate for the respondents submitted to the analysis method used in this research is quantitative method by using a simple linear regression analysis were processed with SPSS software version 18 . The results of this study concluded that the existence of an internal audit will encourage the achievement of implementation of good corporate governance system within the Inspectorate so that later in outline will encourage financial governance system within the district will go well. Although many other factors that will support that have not been investigated as thoroughly as the auditor's own characteristics, auditor ethics deal other factors. Accountability and transparency have become important issues in the management of an organization that disclosure with full disclosure will provide a thorough understanding of users of financial statements. Compliance audit of internal audit affects the implementation of good corporate governance can be seen that the results of testing for compliance audits variable has a probability of 0.041 significance where the value is less than 0.05 . Thus $\mathrm{H} 4$ accepted, this means that the compliance audit of internal audit significantly influence the implementation of good corporate governance in Luwu.
\end{abstract}

Keyword: Internal Audit, Internal Auditor, good corporate governance, accountability, transparency, disclosure

\section{Introduction}

Background: Decentralization and regional autonomy in Indonesia are carried out after the enactment of the Act No. 22 of 1999 on regional autonomy causes partial transfer of authority and responsibility of the central government to local governments (LGs). Law No. 32 of 2004 (Act No. 32/2004) of the Local Government Local Government asserted authority to regulate and manage their own affairs based on the principle of autonomy. There are several things that must be considered and implemented in the transfer of authority to the local government contained in the three main pillars that constitute the basic elements that are interrelated (Prajogo, 2001). These three basic elements are participation, transparency, and accountability of government penyelanggaraan. A good government should run the government openly so that all interested parties in the government can actively berpasrtisipasi, the state administration should also be conducted in a transparent and implementation of the government must be accountable. According Dyah Setyaningrum (2012: 2) accountability and transparency in government is still in early stages of the emergence of awareness of the importance of accountability, but this needs to be appreciated as a form of progress in order to create a clean and authoritative government. Lack of awareness of the government to account for accountability and transparency in government as well as the proliferation of legal cases involving the manipulation of accounting data in a government agency makes 
restless society towards the implementation of public administration and the importance of accounting information. The community is aware of the dissatisfaction management of state assets that can only be enjoyed by the few.

Manipulation or fraud (fraud) Local government accounting data is mostly done by people in local government agencies led to the decline of public trust in local government performance. The rise of such cases raises questions for many people, especially on governance, better known good corporate governance once again lead to the disclosure of the fact that good corporate governance mechanisms that either has not been applied in local government. The role of local government in the provision of public services and the achievement of national development goals become increasingly large. Therefore, there needs to be a system of monitoring, evaluation and performance-measurement systems to measure progress achieved local government. Berger (2011) usefully distinguishes between macro, micro and individual approaches to discuss corporate and government crime and fraud. After the Enron and WorldCom scandals, professional audit bodies revised their rules regarding auditor' responsibility for the detection of fraud (AICPA, 2002; IFAC, 2006), conceptualizing accounting frauds based on an individual decision making model that emphasizes three elements: opportunity, incentive and rationalization. According Mardiasmo (2005: 189), there are three main aspects that support the creation of good governance (GCG), namely monitoring, control and inspection. Examination (audit) is an activity undertaken by a party who has the independence and professional competence to examine whether the results of the government's performance in accordance with established standards.

Agustin (2010) Competency audit and independency audit influence to effectiveness internal audit for good corporate governance. Rusmini (2013) Performance of employee for good corporate governance and productivity. Mulyadi (2002) indicator of auditing is systematic, objective, evaluable, audit report. Mardiasmo (2004) Performance audit systematic, objective for efficiency and effectiveness. This research is consistent with the theory (Prajogo, 2001). These three basic elements are participation, transparency, and accountability of government penyelanggaraan. A good government should run the government openly so that all interested parties in the government can actively berpasrtisipasi, the state administration should also be conducted in a transparent and implementation of the government must be accountable. Performance audit is an objective and systematic audit of the evidence to be able to carry out an independent assessment of the performance of an organization / company (Fibrianto Revelation Nugroho, 2005: 2). Performance audit aims to assist management in auditing and encourage the achievement of objectives effectively, efficiently, and economically, improve and enhance the performance and give consideration to the decision by the responsible party (Deputy of the State Accountant, 2001: 2). As with the research conducted by Rusmini (2013) stated that the performance of employees in order to realize good governance has been running well it can be seen from the productivity that is supported by the ability of employees to overcome difficulties in the public service was satisfactory, quality service where employees can carry out their duties efficiently and responsiveness response personnel to address community complaints. Based on the above description, the author will analyze the effectiveness of the implementation of a performance audit to achieve good corporate governance at the local government carried out by the internal auditors in this case the local government Inspectorate Luwu, so the author is interested in conducting research and presenting it with the title "Effect of Performance Audit of the implementation of good corporate governance Luwu"

Problem Formulation: Based on the description above background, the authors define the problem formulation is: "Is the Internal Audit affect the implementation of good corporate governance Luwu local government?"

\section{Literature Review}

Effect of Implementation of Government Performance Accountability System for Implementation of Good Governance: Accountability, an agency that is realized through the implementation of SAKIP very important to the application of the principles of good governance, namely to obtain reasonable assurance that the objectives of a specific business or activity that would be able to prevent the loss of resources. There are four types of audits are known (Gondodiyoto, 2007: 93), namely:

- Financial audit (financial statement audit) is auditing the financial statements of the company or government organization that will generate a third party opinion on the suitability, accuracy, and completeness of these reports. Financial audits are generally carried out by the company or a 
public accountant who does not have its on others who must follow the accounting principles generally accepted.

- Operational audit / audit performance (operational audits) is the review of each part of the organization's standard operating procedures and methods are applied to an organization with the aim to evaluate the efficiency, effectiveness, and economy (3E)

- Audit compliance (compliance audit) is a work process that determines whether the auditee has followed the procedures, standards and rules imposed by the authorities.

- Audit information systems (information systems audits), IT audit is the process of collecting and evaluating evidence to determine whether the computer system used has been able to protect the assets of the organization, able to maintain the integrity of the data, can help achieve organizational goals effectively, as well as the use of resources owned efficiently.

Effect of Performance Audit of the increased efficiency: Performance audit aims to assist management in auditing and encourage the achievement of objectives effectively, efficiently, and economically, improve and enhance the performance and give consideration to the decision by the responsible party (Deputy of the State Accountant, 2001: 2). Nofianti (2012) in his research stating that the performance audit dimension or variable operational audits of public sector internal audit examined, indicating that the audit performance / operational needs to be improved in almost all SKPDs (SKPD) in Riau Province. The results obtained on the implementation of the performance audit / operations not merely formal truth but is useful for improving the performance of government and public accountability within the framework of achieving good governance. Here are 10 principles that underlie good governance are:

- Participation: Encourage every citizen to exercise the right to express opinions in the decisionmaking process concerning the interests of the public, either directly or indirectly.

- Law Enforcement: Realizing the enforcement of legislation that is fair to all parties without exception, upholding the values that live in the community.

- Transparency: Create mutual trust between the government and ensure ease in obtaining accurate and adequate information yanh.

- Equality: Provide equal opportunity for every member of the community to improve their welfare.

- Responsiveness: Increasing the sensitivity of the organizers of the government against the aspirations of the people without exception.

- Insights Into Home: Building area based on the characteristics and a clear strategy and to involve citizens in the entire development process, so that people feel ownership and take responsibility for the progress of the region.

- Accountability: Improving the accountability of decision makers in order to represent the interests of the wider community.

- Supervision: Increase efforts to supervise the implementation of the government and development to seek the involvement of the private and the public at large.

- Efficiency and Effectiveness: Ensure the implementation of service to the community by using the available resources optimally and responsibility.

- Professionalism: Improving the ability and moral governance to be able to provide service that is easy, fast, accurate and cost affordable.

Relationships Achieve Good Performance Audit in Corporate Governance by the Internal Auditor: Internal control is very important for the wheels of government, especially after the transfer of part of the authorities and responsibilities of the central government to local governments based on the principle of local autonomy. This causes local governments are required to provide accountability reports. Internal controls for Local Government Inspectorate carried out by the so-called internal auditors government can direct, supervise, and measure the wealth of a local resource in order to be better for the implementation of good corporate governance. Nofianti (2012) in his research stating that the performance audit dimension or variable operational audits of public sector internal audit examined, indicating that the audit performance / operational needs to be improved in almost all SKPDs (SKPD) in Riau Province. The results obtained on the implementation of the performance audit / operational is not merely formal but the truth is useful. 


\section{Framework for Thinking}

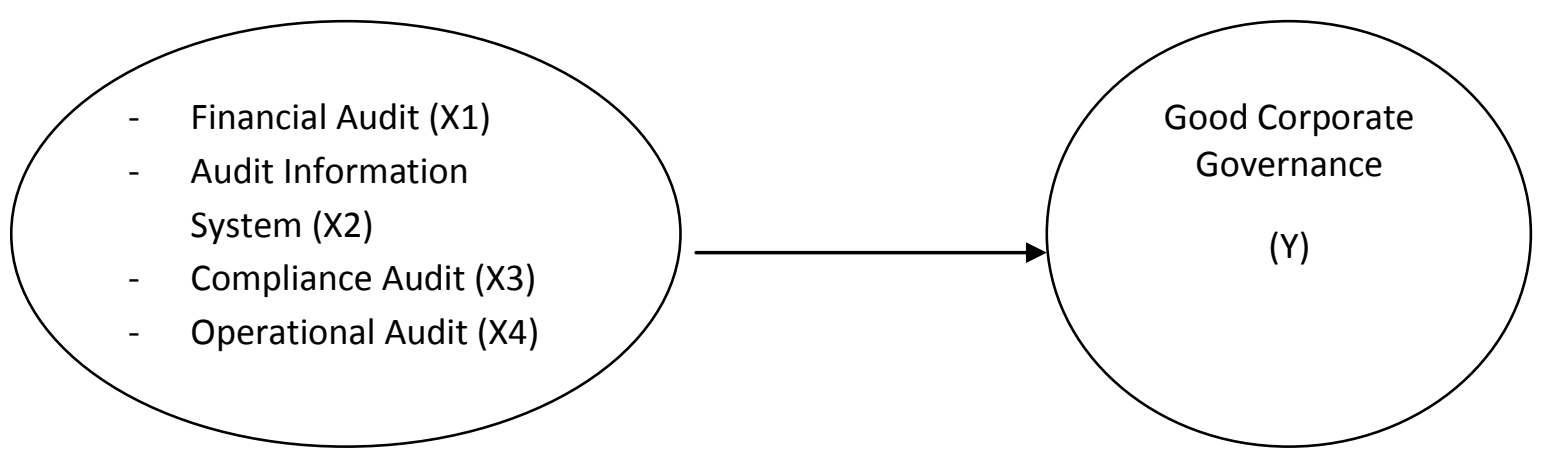

Hypothesis: Based on the background and the formulation of the above problem, the authors propose the following hypothesis: Internal audit is supposed that affect the implementation of good corporate governance Luwu.

Research Objectives and Benefits: The purpose and benefits of the research to be achieved in this study are:

To determine the effect of the Internal Audit of the implementation of good corporate governance in local government Luwu"

\section{Methodology}

Types of Research: This study is a quantitative study that researchers collect information from respondents by using questionnaire. Where the information collection techniques done by compiling a list of questions that are appropriate for submission to the respondent (masri and Sofyan, 2005).

Population and Sample: According to Uma Sekaran (2006: 121.123) population is a whole group of people, events, or things that interest the researcher wants to investigate, while the sample is part of the population, the sample consists of sejunlah member selected from the population. Population and sample in this study are all government internal auditors in Luwu District Inspectorate Office.

Analysis Method: The method of analysis used in this study is a simple linear regression analysis tool SPSS software version 18. The multiple linear regression equation implies that in a regression equation, there is one dependent variable and four independent variables. Multiple linear regression equation was formulated as follows:

Where:

$$
\mathrm{Y}=\mathrm{a}+\mathrm{b} 1 \mathrm{X} 1+\mathrm{b} 2 \mathrm{X} 2+\mathrm{b} 3 \mathrm{x} 3+\mathrm{b} 4 \mathrm{X} 4+\mathrm{e} \ldots \ldots . .
$$

$$
\begin{aligned}
& \text { Y = Good Governance } \\
& \text { X1 = Financial Audit } \\
& \text { X2 = Operational Audit } \\
& \text { X3 = Audit Compliance } \\
& \text { X4 = Audit Information System } \\
& \text { a = constant } \\
& \text { b = regression coefficient }
\end{aligned}
$$

\section{Results and Discussion}

\section{Hypothesis Testing}

Linear regression test: Regression test aims to determine whether there is the influence of independent variables on the dependent variable. The magnitude of the effect of the independent variable on the dependent variable can be calculated simultaneously through a multiple regression equation. 
Table 1: Test Multiple Linear Regression

Coefficients a

\begin{tabular}{llll}
\hline Model & & \multicolumn{2}{c}{ Unstandardized Coefficients } \\
& & B & Std. Error \\
\hline \multirow{4}{*}{1} & (Constant) & 1,047 & 8,087 \\
& Financial Audit & -.573 & .461 \\
& Performance Audit & .594 & .422 \\
& Audit Compliance & 1,333 & .559 \\
& Information Systems Audit & .505 & .263 \\
\hline
\end{tabular}

a. Dependent Variable: Good Corporate Governance

Source: Output SPSS 21.0, 2014

From the table above can be obtained regression formula as follows:

$$
\mathrm{Y}=1.047-0,573 \mathrm{X} 1+0,594 \mathrm{X} 2+1,333 \mathrm{X} 3+0,505 \mathrm{X} 4
$$

From the regression equation above, the constant (a) is equal to 1,047 this means that if there is no change in the variable financial audit, performance audit, compliance audits and audit information system that affects, then the amount of good corporate governance Luwu district 1.047. While the results of multiple regression test for independent variables can be explained as follows:

- Coefficient of financial audits of -0.573 positive striving towards application good corporate governance Luwu (Y). This suggests that the increase in financial audits ssetiap one unit then the variable application good corporate governance Luwu District of 0.573 with the assumption that the other independent variables remain.

- Coefficient of performance audit of 0.594 positive effect on application good corporate governance Luwu (Y). Hali This shows that every one unit increase in performance audit then the variable application good corporate governance Luwu District of 0.594 with the assumption that the other independent variables remain.

- Coefficient of compliance audits of 1,333 positive effect on the implementation of good corporate governance Luwu (Y). This suggests that each increase of one unit of the compliance audit the implementation of good corporate governance variables Luwu of 1,333 with aumsi that other independent variables remain.

- Coefficient of information systems audit of 0.505 positive effect on the implementation of good corporate governance Luwu (Y). This suggests that any increase in one unit of information systems auditing the implementation of good corporate governance variables Luwu of 0.505 with the assumption that the independent variables remain.

The coefficient of determination (R2): This test measures the ability dilkukan for independent variables, namely financial audits, performance audits, compliance audits and audit of the information system application good corporate gavernance Luwu. The results of the determination coefficient in column buffer diliat adjusted R square, which is shown in the following table:

Table 2: Coefficient of determination (R2)

Model Summary b

\begin{tabular}{lllll}
\hline Model & R & R Square & $\begin{array}{l}\text { Adjusted } \\
\text { Square }\end{array}$ & $\begin{array}{l}\text { RStd. Error of the } \\
\text { Estimate }\end{array}$ \\
\hline 1 & $.889 \mathrm{a}$ & .791 & .698 & 2.64758 \\
\hline
\end{tabular}

a. Predictors: (Constant), Information Systems Audit, Financial Audit, Compliance Audit, Performance Audit

b. Dependent Variable: Good Corporate Governance

Source: Output SPSS 21.0, 2014

In the table above shows that the adjusted $\mathrm{R}$ squere coefficient is equal to 0.698 or $69.8 \%$. It was concluded that the dependent variable is the implementation of good corporate governance in Luwu influenced by financial audits, performance audits, compliance audits and audit of information systems .adalah of $69.8 \%$. While the remaining $30.2 \%$ is influenced by other variables that are not included in this study. Figures correlation coefficient (R) at 4:19 table of 0.889 indicates that the relationship between the dependent and independent variables is strong because it has a correlation coefficient above 0.5. 
Table 3: Partial Test results (t-test)

Coefficientsa

\begin{tabular}{|c|c|c|c|c|c|}
\hline \multirow{3}{*}{ Model } & \multirow{2}{*}{\multicolumn{2}{|c|}{$\begin{array}{l}\text { Unstandardized } \\
\text { Coefficients }\end{array}$}} & \multirow{3}{*}{$\begin{array}{l}\text { Standardized } \\
\text { Coefficients } \\
\text { Beta } \\
\end{array}$} & \multirow{3}{*}{$\mathbf{T}$} & \multirow{3}{*}{ Sig. } \\
\hline & & & & & \\
\hline & B & Std. Error & & & \\
\hline (Constant) & 1,047 & 8,087 & & .129 & .900 \\
\hline Financial Audit & -.573 & .461 & -.240 & -1243 & .245 \\
\hline \multirow{3}{*}{$\begin{array}{l}1 \text { Performance Audit } \\
\text { Audit Compliance } \\
\text { Information Systems }\end{array}$} & .594 & .422 & .301 & 1,406 & .193 \\
\hline & 1,333 & .559 & .507 & 2,383 & .041 \\
\hline & .505 & .263 & .372 & 1,921 & .087 \\
\hline
\end{tabular}

a. Dependent Variable: Good Corporate Governance

Source: Output SPSS 21.0, 2014

Partial test (t test): Partial regression testing ( $t$ test) aims to test the effect of each independent variable on the dependent variable partially. To find out how the effect of each independent variable on the dependent variable can be seen by comparing the probability value ( $p$-value) of each variable with a significance level of 0.05 is used. If the p-value less than 0.05 then this shows that the independent variables in partial exercise significant influence on the dependent variable. The test results of the independent variable on the dependent variable individually (partial) were performed by test (Table 4:20) is as follows:

- Hipotesi both stated that the financial audit of internal audit affect the implementation of good corporate governance from 4:20 table can be seen that the test results for the financial audit of the variable has a probability of 0.245 significance where the value is greater than 0.05 . Thus $\mathrm{H} 2$ is rejected, it means that the financial audit of the internal audit does not have a significant influence on the implementation of good corporate governance Luwu.

- The third hypothesis states that the performance audit of internal audit affect the implementation of good corporate governance from 4:20 table can be seen that the results of testing for performance audits variable has a probability of 0.193 significance where the value is greater than 0.05 . Thus $\mathrm{H} 3$ is rejected, it means that the performance audit of the internal audit does not have a significant influence on the implementation of good corporate governance Luwu.

- The fourth hypothesis states that the compliance audit of internal audit affect the implementation of good corporate governance from 4:20 table can be seen that the results of testing for compliance audits variable has a probability of 0.041 significance where the value is less than 0.05. Thus H4 accepted, this means that the compliance audit of internal audit significantly influence the implementation of good corporate governance Luwu.

Simultaneous Testing (Test F): This test was conducted to determine the effect of all independent variables together or simultaneously to the dependent variable using the $\mathrm{F}$ test at a rate of $5 \%$ significance. If the value of the $\mathrm{F}$ test of significance is less than $5 \%$, then there is the influence of all the independent variables on the dependent variable. F test results can be seen in the following table:

Table 4: Simultaneous Testing Results (Test F)

\begin{tabular}{|c|c|c|c|c|c|c|}
\hline Model & & Sum of Squares & Df & Mean Square & $\mathbf{F}$ & Sig. \\
\hline \multirow{3}{*}{1} & Regression & 238627 & 4 & 59657 & 8511 & $.004 \mathrm{~b}$ \\
\hline & Residual & 63087 & 9 & 7010 & & \\
\hline & Total & 301714 & 13 & & & \\
\hline
\end{tabular}

a. Dependent Variable: Good Corporate Governance

b. Predictors: (Constant), Information Systems Audit, Financial Audit, Compliance Audit, Performance Audit

Source: Output SPSS 21.0, 2014

From the table above 4:21 unknown $\mathrm{F}$ test results indicate that the $\mathrm{F}$ count is 8.511 with a significance level of 0.004 . Because the level of significance is smaller than $\alpha(0.004<0.05)$, the H1 is accepted. It can be concluded that all the independent variables in this study together (simultaneously) a significant effect on the dependent variable, namely the implementation of good corporate governance in Luwu. This means that if financial audits, performance audits, compliance audits and audit information systems together increases, the implementation of good corporate governance Luwu (Y) also increases. And 
conversely, if the financial audits, performance audits, compliance audits and audit information systems together to decline, then the implementation of good corporate governance $(\mathrm{Y})$ will also decrease.

\section{Conclusion and Recommendations}

This paper to describe how internal audit can support be Good Corporate Governance in local government, how the auditor capability and quantity can be accept 33 department of the local government Luwu, and this find the less Auditor capacity to do that and independency auditor, professionalisms and quality of auditor and now in Kab Luwu just have 11 auditors. From the above results that the presence of internal audit will encourage the achievement of implementation of good corporate governance system within the Inspectorate so that later in outline will encourage financial governance system within the district will go well, although many other factors that will support that has not been investigated as thoroughly as characteristic auditor itself, ethical auditors deal other factors. This research is consistent with the theory (Prajogo, 2001). These three basic elements are participation, transparency, and accountability of government penyelanggaraan. A good government should run the government openly so that all interested parties in the government can actively berpasrtisipasi, the state administration should also be conducted in a transparent and implementation of the government must be accountable. Accountability and transparency in government is still in early stages of the emergence of awareness of the importance of accountability, but this needs to be appreciated as a form of progress in order to create a clean and authoritative government. Lack of awareness of the government to account for accountability and transparency in government as well as the proliferation of legal cases involving the manipulation of accounting data in a government agency makes restless society towards the implementation of public administration and the importance of accounting information. The community is aware of the dissatisfaction management of state assets that can only be enjoyed by the few. The performance audit can clean government from fraud or corruption and then rule of the internal audit will be good for local government. Recommendation to increase the quantity of auditor and competency auditor for effectiveness and efficiency for support good corporate governance and decreasing the fraud.

\section{References}

Agustin, L. (2010). Analysis of Factors Affecting the Effectiveness of Internal Audit In Achieve Good Corporate Governance. Thesis Syarif Hidayatullah State Islamic University Jakarta. Jakarta.

Berger, R. J. (2011). White collar crime: The abuse of corporate and government power. Boulder, CO: Lynne Rienner Publishers

Dyah, S. (2012). Accountability and Transparency in Government.

Gondodiyoto, S. (2007). Information System Audit: COBIT approach. Partners Media Discourse. Jakarta

Mardiasmo. (2004). Public Sector Accounting. Andi Publisher. Yogyakarta

Mardiasmo. (2005). Public Sector Accounting Edition 2. Publisher Andi. Yogyakarta

Mulyadi. (2002). Auditing Edition 6, Book 1. Publisher Salemba Four.

Nofianti, L. (2012). Local Government Agency Performance Accountability Achieve Good Governance. News Riaupos. Riau.

Prajogo. (2001). Examiner Perspective on the Implementation of the Public Sector Accounting Standards. Journal of Accounting and Public Sector Finance. Public Sector Accounting Compartment Indonesian Institute of Accountants, 02(02). August. pp. 1-8.

Regulation of the Audit Board of the Republic of Indonesia Number 01 Year 2007.Standar State Audit. Jakarta

Government Regulation No. 71 of 2010. Government Accounting Standards. Focus Media. Jakarta

Rusmini. (2013). Employee Performance In Order To Achieve Good Governance In Safe Peasant Village District of Loa Janan Ilir. Thesis Mulawarman. Medan.

Sekaran, U. (2006). Research Methods for Business. Books 1 and 2. Four edition. Jakarta: Salemba Four.

Act No. 22 of 1999 on Local Government.

Law No. 32 of 2004 on Local Government.

Act No. 15 of 2004 on Management and Financial Responsibility State.

Revelation Nugroho, Fibrianto.2005. Performance Audit Procedures In state / local enterprises Office In Finance and Development Supervisory Agency (BPK) Central Java Province. Thesis University of Semarang. Semarang. 